\title{
REGULATOR ROZMYTY DO STABILIZACJI LOTU PLATFORMY UAV
}

\begin{abstract}
Syntezy praw sterowania dla danego obiektu można dokonać, opierając się na znanym modelu matematycznym sterowanego obiektu lub też wiedzy eksperckiej, jak danym obiektem sterować. W pierwszym przypadku najczęściej ma się do czynienie $\mathrm{z}$ klasycznymi regulatorami PID, natomiast $\mathrm{w}$ drugim możliwe jest zastosowanie regulatorów rozmytych. Jednym $\mathrm{z}$ elementów regulatora rozmytego jest baza reguł, budowana najczęściej na podstawie wiedzy eksperta danej dziedziny. Z racji przeznaczenia projektowanego regulatora do stabilizacji lotu niewielkiej platformy UAV, do zbudowania bazy reguł wykorzystano wiedzę modelarza RC, który słownie opisał sterowanie niewielkiego modelu samolotu. Zaprojektowany regulator został zaimplementowany w mikroprocesorowym układzie autopilota. Ze względu na łatwość implementacji wybrano regulator Takagi-Sugeno. Dzięki fizycznej implementacji sprawdzono jego działanie zarówno podczas symulacji, jak również podczas prób w locie, do których wykorzystano model motoszybowca „Cularis”. Przeprowadzone próby w locie wykazały poprawność działania zaimplementowanego regulatora oraz realizacji stawianych przed nim zadań. W pracy opisano regulator rozmyty przeznaczony do stabilizacji lotu platformy UAV. Przedstawiono reguły dla sterowania kanałem przechylania oraz płaszczyzny sterowania przed i po dostrojeniu regulatora. Proces strojenia regulatora przeprowadzano, zmieniając parametry funkcji przynależności bez modyfikacji bazy reguł. Publikacja wskazuje również możliwy kierunek wprowadzania zmian w zaimplementowanym regulatorze.
\end{abstract}

Słowa kluczowe: bezzałogowy statek powietrzny, regulator rozmyty, stabilizacja lotu

\section{Wprowadzenie}

W klasycznych zagadnieniach dotyczących sterowania niezbędna jest znajomość modelu sterowanego obiektu. Zbudowanie odpowiedniego modelu często jest zagadnieniem trudnym, wymagającym niejednokrotnie wprowadzenia uproszczeń. Zastosowanie zbiorów rozmytych umożliwia zbudowanie regulatora bez konieczności znajomości modelu sterowanego obiektu. W takim przypadku regulator może być opracowany jako system ekspercki z wiedzą o sterowaniu

\footnotetext{
${ }^{1}$ Autor do korespondencji/corresponding author: Marcin Dereń, Eurotech Sp z o.o., ul. Wojska Polskiego 3, 39-300 Mielec, tel. (17) 7887760, e-mail: m.deren@eurotech.com.pl
} 
obiektem (w odróżnieniu od systemów z wiedzą o obiekcie). Opis syntezy praw sterowania oparty na modelu obiektu można znaleźć w publikacji [1], przegląd zaś metod syntezy w pracy [2]. Niniejsza praca przedstawia zrealizowany w praktyce regulator rozmyty do stabilizacji lotu niewielkiej platformy UAV. Regulator projektowano z myślą o możliwości budowy systemu sterowania opartego na wiedzy o sterowaniu platformą UAV, niewymagającego identyfikacji obiektu. Po zaimplementowaniu regulatora dokonano jego sprawdzenia podczas symulacji, a następnie podczas prób w locie na modelu RC celem weryfikacji przyjętego założenia.

\section{Regulator rozmyty dla platformy UAV}

Typowy regulator rozmyty składa się z czterech bloków: bloku rozmywania (fuzyfikacji), bazy reguł, bloku wnioskowania oraz bloku wyostrzania (defuzyfikacji). Opis poszczególnych bloków można znaleźć np. w pracy [3]. Dla zwiększenia uniwersalności projektowanego regulatora często wprowadza się dodatkowe bloki normalizacji oraz denormalizacji [4]. Regulator rozmyty może pracować samodzielnie - i taką wersję przyjęto w prezentowanym rozwiązaniu lub w roli nadrzędnego układu dla klasycznego regulatora (np. [5]). Na jakość pracy projektowanego regulatora mają wpływ wszystkie wymienione bloki. Istotnym zagadnieniem jest zbudowanie poprawnej bazy reguł, definiującej sterowanie danym obiektem. W przypadku projektowania systemu z wiedzą o sterowaniu konieczne jest zbudowanie poprawnej bazy reguł na podstawie wiedzy eksperckiej. Wiedzę ekspercką na temat sterowania samolotem można znaleźć w wymienionej już literaturze $[1,2]$ lub też uzyskać od pilota. W przypadku niewielkich platform bezzałogowych wiedzę o sterowaniu można również zaczerpnąć od modelarza sterującego samolotami RC. Modelarz RC nie zna dokładnego modelu matematycznego platformy, potrafi nią jednak sterować. Opisując proces sterowania, używa określeń nieprecyzyjnych, jak ,wychyl lotki mocno w prawo”, „delikatnie oddaj wysokość”, stąd naturalne wydaje się wykorzystanie jego wiedzy do budowy bazy reguł rozmytego systemu sterowania. Taką wiedzę wykorzystano podczas projektowania prezentowanego regulatora.

W pierwszym etapie prac uzyskaną wiedzę wykorzystano do zaimplementowania algorytmu stabilizacji kątów przechylenia i pochylenia. Jako wejścia dla regulatora posłużyły uchyby wartości kątów (różnica wartości zadanej i wartości aktualnej) oraz odpowiadające im prędkości kątowe. Wyjściem regulatora jest zadane wychylenie odpowiednich powierzchni sterowych. W dalszej części opisano regulator dla kąta przechylenia. Regulator posiada dwa wejścia - wejście uchybu kąta przechylenia oraz wejście prędkości kątowej odchylania, które ulegają rozmywaniu. Wyjściem regulatora jest ostra wartość zadanego wychylenia lotek. Dla stabilizacji kąta przechylenia w najprostszej wersji można zbudować regułę - wychyl lotki przeciwnie do obrotu wykonywanego przez platformę, proporcjonalnie do prędkości kątowej. Regulator dla stabilizacji kąta przechyle- 
nia w zaimplementowanej wersji zawiera zbiory wejściowe zdefiniowane jako: uchyb dodatni, uchyb ujemny, prędkość dodatnia i prędkość ujemna. Z prostej kombinacji wynika, że możliwe jest zbudowanie czterech reguł. Przeprowadzone symulacje oraz loty wykazały, że dla kąta przechylenia wystarczające jest zaimplementowanie dwóch reguł:

1. JEŻELI uchyb jest dodatni I prędkość jest ujemna, TO wychyl lotki w prawo.

2. JEŻELI uchyb jest ujemny I prędkość jest dodatnia, TO wychyl lotki w lewo.

Wykorzystując jedynie te dwie reguły, jak wykazały przeprowadzone próby, regulator potrafił wypracować sterowanie konieczne do utrzymania pożądanej wartości kąta przechylenia. Na rysunku 1. przedstawiono płaszczyznę sterowania zaimplementowanego regulatora rozmytego. Jako funkcje rozmywania wybrano arbitralnie nieliniowe funkcje klasy s oraz klasy z. Zarówno uchyb, jak i prędkość kątowa zostały znormalizowane w celu osiągnięcia większej uniwersalności rozwiązania. W przypadku regulatora rozmytego dla stabilizacji kąta pochylania baza reguł składała się z czterech reguł, wynikających z możliwych kombinacji zbiorów zdefiniowanych jak dla kąta przechylenia. Praktyczne próby z zastosowaniem jedynie dwóch reguł nie przyniosły zadowalających rezultatów.

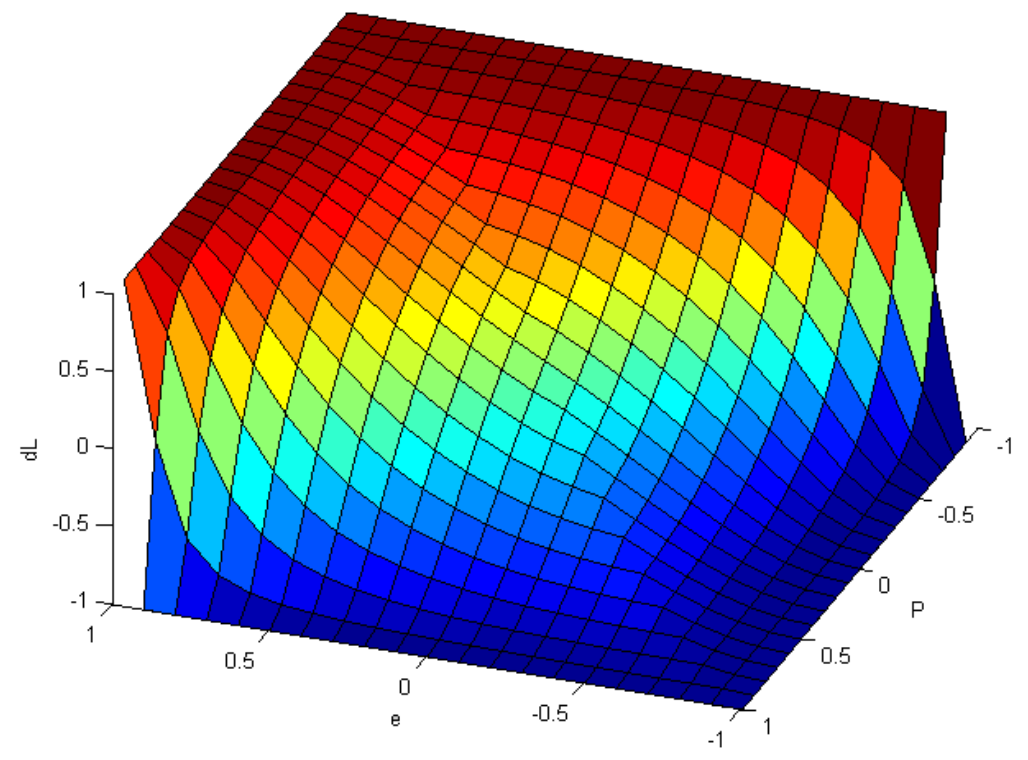

Rys. 1. Wyjściowa płaszczyzna sterowania regulatora

Fig. 1. Initial control plane of the controller 


\section{Implementacja regulatora i próby w locie}

Opisany regulator został zaimplementowany na 32-bitowym mikrokontrolerze w języku C. Wybrano implementację regulatora Takagi-Sugeno, w którym następniki reguł przyjmują określone wartości. Implementacja została poddana próbom zarówno na stanowisku symulacyjnym, jak i podczas prób w locie. Podczas testów symulacyjnych wykorzystano model zbudowany na podstawie pracy [1] oraz stanowiska HIL (ang. hardware in the loop). Obliczenia dla modelu były wykonywane na komputerze klasy PC, obliczenia regulatora zaś w układzie mikroprocesorowym. Wymiana danych pomiędzy modelem a regulatorem odbywała się przez magistralę CAN. Przy domyślnych ustawieniach regulatorów wystąpiło znaczne przeregulowanie oraz oscylacje wartości kąta przechylania, co pokazano w pierwszej części wykresu przedstawionego na rys. 2. Druga część wykresu przedstawia działanie regulatora po jego dostrojeniu, dokonanym poprzez zmianę parametrów funkcji przynależności.

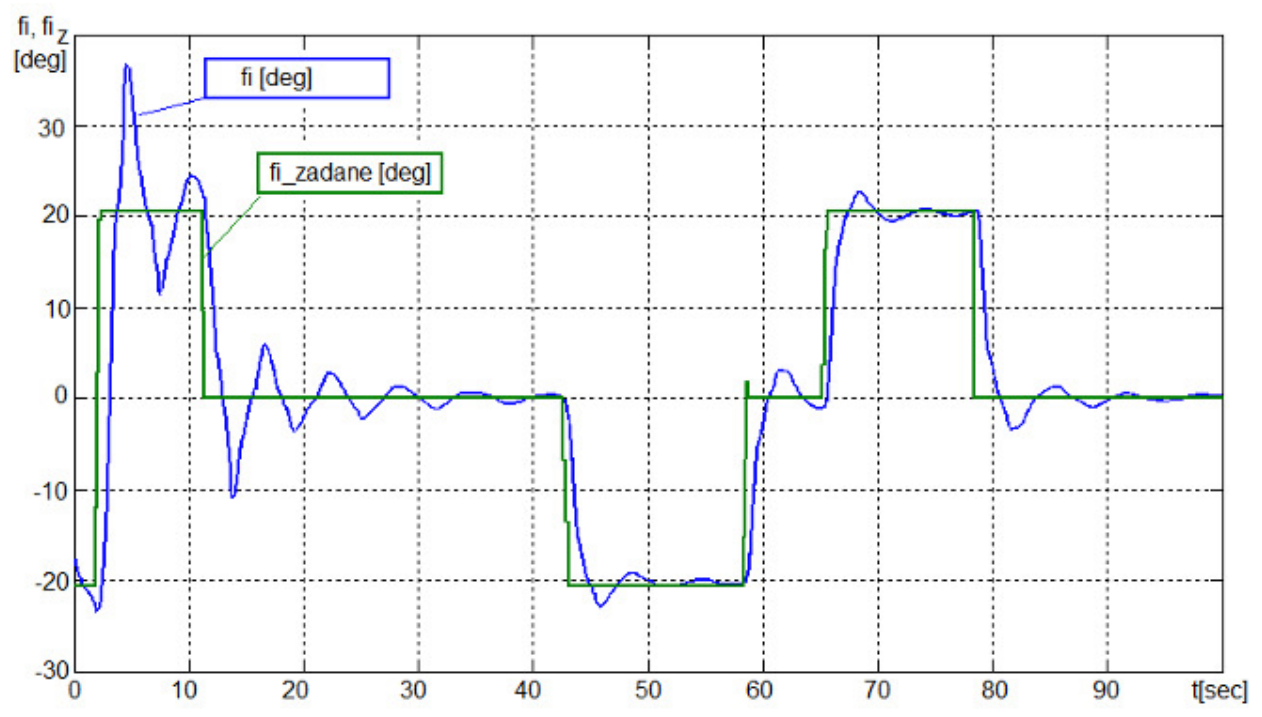

Rys. 2. Działanie regulatora - dla wartości domyślnych (do $40 \mathrm{~s}$ ) oraz po zmianie wartości parametrów funkcji przynależności

Fig. 2. Controller operation - for default values (up to $40 \mathrm{~s}$ ) and after change of the values of membership function's parameters

Do prób w locie wykorzystano model motoszybowca „Cularis”. Przyjęto następujące podstawowe parametry modelu (za producentem [6]):

- rozpiętość - $2610 \mathrm{~mm}$,

- długość kadłuba - 1260 mm,

- masa modelu (szybowiec) - $1400 \mathrm{~g}$, 
- masa modelu (elektryk) - $1680 \mathrm{~g}$,

- powierzchnia nośna - $55 \mathrm{dm}^{2}$,

- obciążenie powierzchni nośnej - $27 \mathrm{~g} / \mathrm{dm}^{2}$,

- sterowanie: wysokość, kierunek, lotki, klapy, regulacja silnika.

Pierwsze przeprowadzone próby wykazały zgodnie z oczekiwaniami konieczność dostrojenia regulatora. Podobnie jak w przypadku symulacji, zmianie uległy funkcje fuzzyfikacji (poprzez zmianę parametrów funkcji przynależności), nie zmieniano natomiast bazy reguł, metod wnioskowania i defuzyfikacji. W trakcie kolejnych prób eksperymentalnie dokonywano zmiany parametrów regulatora, aż do uzyskania zadowalającego efektu. Powierzchnię sterowania regulatora po jego dostrojeniu przedstawiono na rys. 3. Jak nie trudno zauważyć, powierzchnia sterowania zachowała charakterystyczny kształt (jak na rys. 1.), wynikający z zastosowanych zbiorów przynależności oraz reguł wnioskowania. Tym samym można wskazać dalszy kierunek budowy regulatora uniwersalnego dla danego typu platformy poprzez kształtowanie charakterystyk zbiorów wejściowych oraz zakresów normalizacji prędkości i uchybów sterowania.

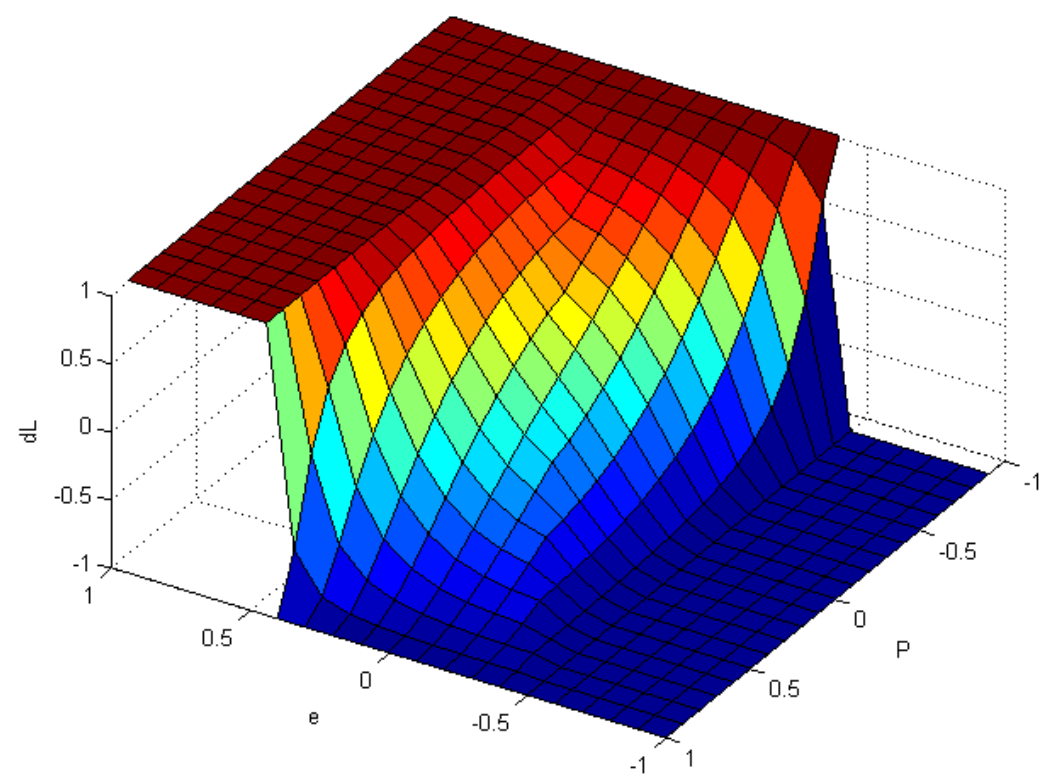

Rys. 3. Płaszczyzna sterowania regulatora

Fig. 3. Control plane of the controller

\section{Wnioski}

Przedstawiony prosty regulator rozmyty okazał się skutecznie spełniać postawione zadanie stabilizacji. Największą zaletą zastosowania regulatora rozmytego wydaje się być fakt braku konieczności znajomości dokładnego 
modelu sterowanej platformy. Strojenie regulatora rozmytego przy przyjętych funkcjach przynależności sprowadza się do zmiany parametrów tych funkcji, bez konieczności modyfikacji bazy reguł czy metod wnioskowania. Zaimplementowany regulator można ulepszyć poprzez wprowadzenie członu całkującego lub dodanie dodatkowych przedziałów funkcji przynależności. Można również wzbogacić bazę reguł kosztem większego skomplikowania procesu dostrajania.

\title{
Literatura
}

[1] Bociek S., Gruszecki J.: Układy sterowania automatycznego samolotem. Oficyna Wydawnicza Politechniki Rzeszowskiej, Rzeszów 1999.

[2] Gruszecki J.: Wybrane metody projektowania algorytmów sterowania obiektami latającymi, [w:] Wybrane zagadnienia sterowania obiektami latającymi, praca zbiorowa pod red. J. Gruszeckiego. Oficyna Wydawnicza Politechniki Rzeszowskiej, Rzeszów 2011.

[3] Rutkowski L.: Metody i techniki sztucznej inteligencji. PWN, Warszawa 2009.

[4] Piegat A.: Modelowanie i sterowanie rozmyte. Wydaw. Exit, 2003.

[5] Kopecki G., Pieniążek J., Tomczyk A.: Koncepcja systemu wspomagania pilota w przestrzeni ograniczeń eksploatacyjnych samolotu lekkiego, [w:] Wybrane zagadnienia sterowania obiektami latającymi, praca zbiorowa pod red. J. Gruszeckiego. Oficyna Wydawnicza Politechniki Rzeszowskiej, Rzeszów 2011.

[6] www.multiplexusa.com/model-kits/cularis.html.

\section{FUZZY LOGIC CONTROLLER FOR UAV FLIGHT STABILIZATION}

\begin{abstract}
The synthesis of control algorithms for a given object can be accomplished in two ways. The first one is based on the mathematical model of the controlled object. The other method uses the expert's knowledge of how to control the object. The former approach usually means applying classic PID controllers, whilst the latter enables using fuzzy logic controllers. One of the crucial elements of fuzzy logic controller is the knowledge base with rules formulated usually by an expert. Due to the fact that the controller described here is intended to stabilize the flight of a relatively small UAV platform, the knowledge of a RC model expert (who described the process of a model plane controlling) has been used for establishing the knowledge base rules. The controller has been implemented in the microprocessor system of the autopilot. Takagi-Sugeno controller has been chosen in order to provide an easy implementation. The physical implementation enabled checking controller's work both during a flight simulation and a real flight test. The latter has been carried out using „Cularis” glider. The real flight tests proved the implemented controller was able to work properly and meet all the expectations. The article describes a fuzzy logic controller intended to stabilize the flight of UAV platform. It also contains a description of rules for controlling roll direction and control surface, both before and after controller's tuning. The controller's tuning process has been accomplished by the change of
\end{abstract}


membership function parameters, without the modification of the knowledge base. In addition, the article points out the direction of possible future changes in the implemented controller.

Keywords: unmanned aerial vehicle, fuzzy logic controller, flight stabilization

DOI:10.7862/rm.2013.37

Otrzymano/received: $25.10 .2013 \mathrm{r}$.

Zaakceptowano/accepted: 22.11.2013 r. 